\title{
Media of Exchange and Liquid Assets of Political and Market Enterprises: A New Monetary Perspective on Medieval French Monetary Mutations
}

\author{
Thomas Marmefelt \\ 1 University of Södertörn, Department of Social Sciences, \\ ${ }^{2}$ Åbo Akademi University, Åbo/Turku, \\ ${ }^{1}$ Sweden \\ ${ }^{2}$ Finland
}

\section{Introduction}

Liquidity constitutes a crucial link between the financial system and the real economy. Schumpeter (1911) argues that credit gives entrepreneurs the additional purchasing power required to realize innovations, which contribute to qualitative improvement of the economic process. In other words, bankers inject the liquidity required for innovation. However, following Austrian business cycle theory (see e.g. Mises, [1912] 1924, 1928; Hayek, 1929, 1931, Huerta de Soto, 2006), credit creation may cause economic cycles by creating an artificial boom that leads to a bust, that is harmful injections of liquidity cause business cycles.

In his formalization of Austrian business cycle theory within a capital-based macroeconomic model, Garrison (2001) finds that credit expansion yields unsustainable growth because it makes the market rate of interest lower than the natural rate of interest, which reflects consumers' intertemporal preferences. Huerta de Soto (2006) argues that credit creation unbacked by real saving gives malinvestment that distorts the production structure because the latter no longer corresponds to what consumers voluntarily would maintain.

This paper combines these two perspectives and argues that liquidity of enterprises in the real economy provided through credit creation by the financial system ex ante must be absorbed by innovation desired by consumers ex post. Hence, sustainable growth requires that the financial system, through a trial-and-error process, finds the correct liquidity which meets the financing needs of innovation desired by consumers.

What do we mean by liquidity? According to Yeager (1968), there are two concepts of liquidity; one is the amount of the medium of exchange and the other the total purchasing power of firms and individuals available from their asset holding and borrowing possibilities. He argues that the actual medium of exchange constrains the total purchasing power of firms and individuals, because attempts to sell liquid assets or borrow would 
mean declining prices of financial assets, higher interest rates, and tighter credit rationing. Following Gurley and Shaw (1955), Yeager stresses that asset preferences limit the expansion of near moneys if money supply is constant.

Similarly, Hicks ([1967] 1979) stresses that John Maynard Keynes used two different concepts of liquidity; one is money in the General Theory and the other is the relative concept of more or less liquid assets in the Treatise; the former Hicks calls fully liquid and the latter more or less liquid. He argues that, like real assets, financial assets may be categorized as running, reserve, or investment assets; money and trade credit are running assets, some level of liquidity is necessary - at least more or less liquid - for reserve assets, which represents the precautionary demand for money, while industrial assets may be interestbearing and possibly illiquid. Hicks argues that banks put strains on their reserve assets by giving credit, which can be contracted, thus forcing industrial clients to draw money from their running assets, while the monetary authorities may increase liquidity of banks by purchasing securities. In Hicks's (1977) view of the credit economy, representing Keynes's non-competitive banking system, the financial system consists of a monopolistic core and competitive mantle, while the rest of the economy is called industry, whose real investments require the core to increase its liability money.

Consequently, the amount of the medium of exchange constrains liquidity, since increased real investments when money supply is constant require that liquidity is reduced, either in the mantle, in case of borrowing, or in industry, in case of drawing on reserves. However, Greenfield and Yeager (1983) propose the BFH system, which lacks base money and separates the unit of account, defined by the government as a comprehensive commodity bundle, from privately issued media of exchange subject to competition. In such a system of monetary separation, the amount of the media of exchange is demand-driven, because there is no base money impeding them, while payments will be made by transfer of ownership shares in BFH funds, mutual fund banks, a blend of banks and mutual funds. The financing requirements of the real economy determine the amount of the media of exchange and thereby the liquidity. Liquidity as the required purchasing power of agents in the real economy, in terms of more or less liquid assets, would determine liquidity as the amount of media of exchange, the fully liquid assets.

While the BFH system represents what Cowen and Kroszner (1987) call a complete functional separation of unit of account from medium of exchange, in pre-modern times, there has been at least a partial separation in Europe from Charlemagne to the French Revolution (see Einaudi, 1936; Einzig, 1966), implying a distinction between imaginary money - the measure of value, the unit of account - and real money - medium of exchange, various metal coins. This paper analyzes monetary mutations of debasement and enhancement and the liquidity of political and market enterprises, considering medieval French monetary mutations from the perspective of new monetary economics. A theoretical interpretation by means of new monetary economics of medieval French monetary mutations will be made, using the literature on this historical phenomenon.

\section{Monetary separation and liquidity: An evolutionary perspective}

By liquidity this paper means the liquidity of political and market enterprises, which may be studied by means of fiscal sociology. According to Wagner (2007), the real economy consists 
of political and market enterprises that operate in the state and the market, which are two arenas of interaction, constituting the public squares and the market squares of society that are linked together by the economy-wide network of political and market enterprises. He considers both the state and the market as emergent orders with their own set of enterprises, connected through links between market enterprises and political enterprises. In his view, taxation provides the equity of political enterprises in the state, while fiscal phenomena emerge through human interaction, like market phenomena, thus implying that the state budget is an outcome of an evolutionary process. In that process, parliamentary assemblies are intermediaries connecting taxpayers with political entrepreneurs.

However, as Wagner argues, taxpayers, who sponsor a political enterprise, may leverage their own capital with capital provided by other taxpayers, who are forced investors. Accordingly, societies have different kinds of networks of political and market enterprises, which all need sufficient liquidity to conduct their real investments and deal with uncertainty. Both political and market enterprises look for additional purchasing power to fund their investments.

Monetary separation may influence the liquidity of political and market enterprises, as Greenfield and Yeager's (1983) proposed BFH system illustrates. In the BFH system, monetary separation means a functional separation between a physically defined unit of account and privately issued media of exchange; the unit of account being defined by the government as a nearly comprehensive commodity bundle and the privately issued media of exchange being subject to competition.

In the BFH system, the amount of the media of exchange is demand-driven, because there is no base money impeding them. As Yeager (2001) argues, money is an instrument of financial intermediation and the quantity of money changes with the demand for media of exchange in an economy without base money, using the BFH system. Consequently, with monetary separation the liquid assets of political and market enterprises giving them sufficient purchasing power determine the amount of the media of exchange.

Monetary separation of the medium of exchange from the unit of account with non-tangible means of payment is the basic feature of new monetary economics (Cesarano, 1995), to which the BFH system belongs. Cowen and Kroszner (1994) modifies the BFH system to develop an evolutionary account why traditional monetary functions, medium of account and medium of exchange can be separate assets rather than a single asset, money. They compare the viability of the laissez-faire BFH system with other commodity bundle media of account systems: directly convertible media with a limited bundle and a governmental compensated dollar. Cowen and Kroszner define five functions of money:

i. Store of value: a durable asset or commodity, which serves as an intertemporal abode of purchasing power;

ii. Medium of exchange: an asset or commodity which is held for purposes of indirect exchange and can be transferred to make purchases and retire debts;

iii. Medium of settlement: an asset or commodity which is delivered to extinguish the legal claims that the payee has upon the payer;

iv. Medium of account: a standard in which prices and debts are quoted;

v. Unit of account: a specific quantity of the medium of account. 
In the BFH system, the nearly comprehensive commodity bundle is the medium of account, in which the unit of account is physically defined. The medium of settlement is the redemption medium of Yeager and Greenfield's (1989) indirect convertibility, according to which banknotes and deposits would be redeemable in some redemption medium, say gold. In the BFH system, indirect convertibility pegs the price level, since it requires banks to redeem media of exchange of other banks with an amount of gold, or some other redemption medium, giving arbitrage that reverses any deviation of the price of the bundle from its defined price (Woolsey, 1992). Media of exchange are redeemed in some redemption medium, some commodity or security, in amounts equal to the medium of account of the commodity bundle defining the unit of account (Woolsey \& Yeager, 1994). In other words, $x$ units of a medium of exchange are redeemed indirectly in the quantity of some redemption medium having the same current market value as $x$ commodity bundles, defining the unit of account (Yeager, 2001).

While Greenfield and Yeager try to design a system with monetary separation, Cowen and Kroszner take an explicit evolutionary approach, combining Menger's (1892a,b) theory of the evolution of money, in which money evolves to overcome the inconvenience of barter with Wallace's (1983) legal restrictions theory, according to which without any legal restrictions interest-bearing securities would be preferred to money. While Menger argues that media of exchange evolve to overcome the inconvenience of barter, Cowen and Krozner (1994) argue that the development of media of account is historically and logically prior to the development of media of exchange. They examine how financial innovation separate media of account from media of exchange and settlement in historical, current, and hypothetical future economies, stressing that change come about as technological and institutional constraints change, while regarding the net return on media of exchange and settlement as a driving force behind their evolution. Considering legal restrictions, the Act of 1765 raised the impediments to interest-bearing notes in Scotland, as a consequence of the prohibition of the option clause, which gave interest to banknote holders during the postponement of redemption (Cowen and Kroszner, 1989).

According to Cowen and Kroszner (1994), increases in asset liquidity, financial innovation, and new transaction technologies decrease the importance of fixed nominal value demand deposits, and liquid securitized assets traded directly through mutual funds bypass traditional banks, while competition in financial markets brings about multiple media of account, exchange, and settlement. In particular, they stress that multiple media of account have been common throughout history. Their story of the evolution of media of account and exchange take place in the following stages:

1. Barter with media of account: Media of account to facilitate trade as language that communicates price information

2. Credit transactions as a substitute for the use of medium of exchange: Intertemporal barter

3. Separate media of exchange easy to store, divide and carry: Generally accepted exchange media arise as the most salable or liquid of assets

4. Unification of medium of account and medium of exchange in a single asset or commodity: media of exchange produced in homogeneous units and more liquid, eventually becoming a commonly understood value

5. New exchange media evolve: monetary evolution continues; assets with superior pecuniary returns displacing extant exchange media assets 
They put the Mengerian story, where marketable intermediary commodities to overcome the double coincidence of wants evolve and generally acceptable media of exchange arise as the most salable or liquid of assets through a market process, at the third and fourth stages. They argue that media of account evolve before media of exchange and that these two functions are eventually united in a single commodity or asset, as liquidity plays an increasing role in the choice of medium of account. The reason for liquidity being so important, they point out, is that the medium of exchange comes to represent a commonly understood value by being more liquid than the medium of account, but they also stress that the development of homogeneous units for media of exchange is a relatively recent historical development.

Nevertheless, they have a process orientation and regard monetary evolution as continuous, so new media of exchange will evolve, as the economy-wide adaptation of media of account and exchange leads to trading posts - spot and futures markets - for assets that bear pecuniary returns that begin to displace extant media of exchange, involving a preference for assets in form of electronic or bookkeeping entries rather than physical form. This is the introduction of intangible money that Cesarano (1998) considers as a key institutional change in the $21^{\text {st }}$ century.

According to Cowen and Kroszner (1994), technological progress increases the pecuniary benefits of using claims to productive assets as media of exchange and settlement and may eventually exceed the cost of separating the media of account from the media of exchange and of settlement, and the technologies that support monetary separation also lower the costs of multiple exchange media. Exchange would be based upon a medium of account value. However, multiple media of exchange and settlement would not be enough. Cowen and Kroszner point out that multiple media of account prevail in the early and the later stages of financial evolution, in advanced stages due to heterogeneous traders in terms of endowments and desired portfolio position. The media of account have a communicative function.

Yeager (1998) views money as a record-keeping device, a mechanism to facilitate trade, stressing that money prices convey information that gives coordination. This would be the medium of account function of money, but also the medium of exchange function has informational aspects. According to Cesarano (1999), the Mengerian selection process for commodities with the highest "salability" was guided by the search for informationally more efficient ways of settling transactions. Yeager (2000) argues that money is an example of institutional evolution from a commodity to a clearing device. Money becoming a clearing device opens up for monetary separation again. Dembinski and Perritaz' (2000) regard the weakening of money as a thing and increasing complexity of institutional arrangements as a break-up of money.

From a Searlean perspective, money prices possess language-like symbolism (Horwitz, 2007; Marmefelt, 2009). As Searle (1999) argues, all institutions but language require language or language-like symbolism. Searle's description of the symbolizing role of language as the foundation of the social universe is quite analogous to the symbolizing role played by money prices in the economic universe, and money prices communicate contextual and tacit knowledge, which is beyond the capacity of language (Horwitz, 2007). Market prices 
possess a language-like symbolizing function, but language is required to establish a shared meaning of money, property, exchange, and price, in order to give market prices that function (Marmefelt, 2009).

Stressing money's role as record-keeping device facilitating the clearing of multilateral exchanges, Yeager (1998) regards the unit of account as vocabulary, grammar, and idioms, while the media of exchange constitute particular documents and speech recordings. The latter may become electronic. Cowen and Kroszner (1994) points out that assets with superior pecuniary returns begins to displace the extant medium of exchange and market participants will prefer assets in the form of electronic or bookkeeping entries, while liquidity increases. However, they also point out that both the early and the late stages of financial evolution involve considerable multiplicity among the media of account. Hence, these are characterized by multiple vocabularies, grammars, and idioms and selection among them.

For communication it is essential that they remain clear, which requires a stable unit of account. Unless price signals are clear, communication by means of prices becomes less efficient and investments more inconsistent, thus forcing the financial system to constrain liquidity. In the BFH system that Greenfield and Yeager (1983) propose, a physically defined unit of account, as the total market value of definite quantities of specific commodities, is separated from the media of exchange subject to competition, and since the unit of account has its general purchasing power fixed by definition, it is a stable unit for pricing, invoicing, accounting, economic calculation, borrowing and lending, and writing contracts. However, it is based upon weights that represent the worth of the commodities at the time of definition. The commodity bundle is nearly comprehensive, including most commodities (Woolsey \& Yeager, 1994), thus giving stability for some time period, but as the economy evolves over time, the worth of the commodities in the commodity bundle may shift, both in absolute and relative terms.

A physically defined unit of account in terms of a bundle of commodities cannot maintain itself in the long run. Some commodities may become obsolete for industrial use and new may enter, while innovation will increase the services obtained from physical quantities of various commodities. For example, the refrigerator and the freezer decreased the worth of salt in food conservation, and more fuel efficient car engines decreased the quantity of crude oil required to drive a certain distance.

The economic value in terms of services we may obtain from the various commodities to be included in the bundle defining the unit of account is what really matters, not their physical quantities. Among classical economists, Steuart (1810) argues that the money of account is the ideal scale of equal parts that performs to, with regard to value what degrees do to angles, and when it becomes realized in gold and silver, it becomes the price and the measure of value, because only the money of account constantly preserves an equal value, the only permanent and equal scale. As examples he mentions the florin banco of the Bank of Amsterdam and the macoutes on the coast of Angola. The first he calls "an invention, of men instructed in the arts of commerce" that provides a standard on which the prices of all things are regulated, while precious metals, with their intrinsic value, vary with regard to this standard. He points out that bank money is unaffected by 
alterations in weight, fineness, and denomination of coins, while the macoute, which is divided in ten pieces, operates where there is no real money, but is used to estimate worth of things. According to Steuart, the money of account cannot be fixed to any material substance. This means that the use of a bundle of commodities, defined by weight, is problematic.

Meulen (1934) clarifies the importance of an invariable unit of value, referring to Steuart's money as arbitrary scale of equal parts, invented for measuring the value of things vendible and not fixable in perpetuity to any commodity. He also criticizes John Stuart Mill for describing the macoute, but failing to see that it constitutes an invariable unit. Meulen's historical examples of invariable units include:

i. $\quad$ the bank-notes in England during the Bank Restriction Act (1797-1819), where drainage of gold made commodities offered in bank-note prices only;

ii. the Assignats in France, which were a medium to pay government debt rather than a true credit medium, but still managed to function as unit of price before the real depreciation of the paper franc; and

iii. standardized paper as price unit in both the United States during the Civil War and in Russia with the practically inconvertible rouble notes.

Considering gold as unit of value, Meulen argues that a commodity unit of value has disadvantages, that a valuable metal used to measure value is a yard-stick made of guttapercha, and that stability in the unit of value requires that one fixes upon and standardizes the worth of some particular commodity at some particular time, stressing that value represents worth, not weight. He lets the banknote become the invariable unit of price, while the price of gold fluctuates with supply and demand. His reform is inspired by the French banquier system, a bill of exchange system where sellers draw drafts on their customers and their bankers discount these drafts for them that existed in France for some time and later in Belgium, Switzerland, Germany, and Austria. For commodity money systems, Sargent and Velde (2002) make a related distinction between coins exchanging by weight and coins exchanging by tale, and they point out that fiat money implies exchanges by tale. We may say that worth is reflected in tale.

However, also a banknote system may be problematic for the invariability of value. Wicksell ([1906] 1966) provides an example from 18 th century Sweden, the inconvertible notes issued by Sveriges Riksbank from 1745 that were too abundantly issued, especially during the Pomeranian War, causing the notes to depreciate relative to silver, which eventually led to the appreciation of the specieriksdaler - Sweden's international coin with virtually invariable weight and metal content - and the riksdaler Hamburger banco, ${ }^{1}$ used for most bills of exchange, relative to the bank notes in daler or mark. Consequently, the increase of liquid assets of political enterprises could be detrimental to the invariability of value of a banknote system. The determination of an adequate level of liquidity in a credit economy is therefore of great importance.

1 The Hamburger banco provided a unit of account. Wicksell points out how all great merchants required that all payments to them be calculated in the Hamburger banco and made settlements through giro payments. 


\section{Liquidity in the credit economy}

Cesarano (1999) refers to Wicksell's ([1906] 1966)pure credit economy as a main contribution to the understanding of a payment system devoid of currency, pointing to the accounting system of exchange possibly evolving today. The pure credit economy may be the direction to which the advanced economies today evolve. Information and communication technology plays an important role. Cesarano (2008) explicitly says that it moves actual economies towards a Wicksellian credit economy by making tangible money obsolete, while Dembinski and Perritaz (2000) argue that it drives a break-up of money, meaning that more specialized instruments and institutional arrangements take over the traditional functions of money. Hence, information and communication technology contributes to the evolution of an economy based upon intangible money that provides liquidity.

Based on Keynes, Hicks (1977) develops a credit economy model with a banking core, a financial mantle, and an outer industry as three concentric sectors, and he shows that an increase in real investment with constant money supply reduces liquidity somewhere, either in industry itself, if drawing on its reserves, or in the financial mantle, if borrowing. As Leijonhufvud (1984) argues, Hicks' credit economy model implies that bank financing of investment, which increases productivity, gives an endogenous increase in the money supply. Monetary separation may be helpful in this respect.

In Greenfield and Yeager's (1983) proposed BFH system, where monetary separation is complete, the amount of the media of exchange is demand-driven, because there is no base money impeding them, since mutual fund banks simply adjust fund shares depending on the portfolio selection of market participants between money and bonds. Provision of cheap credit to overcome under-consumption is the solution Meulen (1934) provides, arguing for the adequacy of the Scottish option clause, involving deferred redemption with interest being paid during the time the payment was deferred.

According to Meulen, credit is necessary in any advanced system of division of labor and legal restrictions cause capital to go only where the demand is extremely keen, and the combination of a limited exchange medium volume and high dividends to shareholders lead to an accumulation of the medium of exchange in the hands of the financial class not performing due labor. Having the gold standard as frame of reference, he continues that the banker, whom he calls the professional judge of commercial integrity and ability, is precluded from making long-term loans due the danger of being forced to redeem media of exchange into gold, forcing employers to turn to the unprofessional public. He mentions several disadvantages:

i. Employers obliged to submit themselves to a board of directors

ii. The banker as professional judge of commercial worth more likely to encourage true ability than the untrained public

iii. Fraudulent company promotion due to the limited liability company, an irresponsible organism without personal responsibility

iv. Credit extended at a fixed rate by a banker, in contrast to shareholders who provide equity on condition of sharing increased profits proportionally

This is the opposite of the more recent idea of capital markets as markets for corporate control. Not only does Meulen strongly advocate a credit economy rather than a loanable funds economy, but in his credit economy, the credit system will make sufficient injections of credit to monetize the powers of workers, thus preventing over-production. Meulen's 
ideal system of credit uses credit tokens, which are confidence-based, thus ruling out the need for redemption into gold; being issued by a reliable person who would redeem debt in due time is all a banknote requires. In other words, the media of exchange, the credit tokens, will be demand-driven to achieve full employment. The establishment of such a system implies that the economy moves from assignment of function in virtue of physical structure to pure status, like Searle (1999) characterizes the move from commodity money to fiat money. The media of exchange of credit economies have a pure status function and lack a function in virtue of physical structure.

Wicksell ([1906] 1966) argues that credit is a remedy to scarcity of money and explains how bills of exchange increase virtual velocity, before turning to the development of banking with certificates of deposit and banknotes, and the rise of the modern bank when deposit and giro banks started lending out deposits. In his pure credit system, credit is substituted for gold and the value of money is separated from gold. His essential issue is the exchange value of money and he considers an index based on the product of commodity price and quantity, but he rejects the possibility of such an index having an invariable value, because commodities mean different things to different individuals. An inconvertible paper coin would, according to Wicksell, imply the replacement of gold by credit media, and he stresses that the unit of value should be independent of material things. Hence, Wicksell's analysis implies an abstract medium of account, like Meulen's analysis. With the development of intangible money, Wicksell's paper coin may, in turn, be replaced by an intangible coin. However, liquidity is not limited to coins and banknotes.

Gurley and Shaw (1960) show that non-monetary indirect financial assets contribute to liquidity. They classify financial markets into submarkets for:

1. primary securities: bonds, equities, mortgages, and consumer debt;

2. indirect securities: (i) money: means of payment; (ii) non-monetary indirect securities: time and savings deposits, savings and loan shares

They describe how a short-term security, the Treasury bill, reduces the demand for money, but also how a Treasury issuing bills is a competitor to the monetary system, and that nonmonetary indirect financial assets grow. This can be seen as an injection of liquidity into political enterprises by market enterprises, but Gurley and Shaw point out that Treasury bills constitute a liquidity substitute and may be used by banks to regulate their own liquidity to obtain a desired level of reserves to primary securities. For example, banks could decrease their liquidity by selling Treasury bill and buying bonds. Hence, the existence of non-monetary indirect financial assets means that the form of liquidity between money and non-monetary indirect financial assets may vary.

Gurley and Shaw's non-monetary financial intermediation corresponds to intermediation in Wicksell's pure credit economy, or Meulen's ideal system of credit. Gurley and Shaw point out that non-monetary intermediaries may increase the supply of loanable funds by demanding primary securities, thus raising the total supply of loanable funds if not offset by a reduction if demand by spending units and the monetary system. ${ }^{2}$ Consequently, there are ways to expand liquidity of enterprises beyond money.

\footnotetext{
${ }^{2}$ Loanable funds have in their analysis a more general meaning, including credit.
} 
Monetary separation may play an important role in this process. The historical experience of liquidity with partial monetary separation in pre-modern economies, facing monetary mutations, such as the medieval French economy, may provide some valuable lessons that shed light on liquidity with the BFH system, as an alternative system of complete monetary separation.

\section{Liquidity with medieval imaginary and real monies subject to monetary mutations: The French experience in the light of new monetary economics}

The medieval French economy was subject to monetary mutations under a monetary régime of partial monetary separation. As such, it provides a case in point of monetary practices in pre-modern Europe. The monetary system in pre-modern economies in Europe from Charlemagne to the French Revolution was characterized by partial monetary separation, having two complementary monies: imaginary money and real money. Fantacci (2005) calls this period in European monetary history, a remarkably long period in which precious metals were used as means of payment without being defined as standard of value, during which ideal money or imaginary money was used as unit of account, the measure of value without having its metal equivalent legally defined, and real money as medium of exchange in the form of coins made of gold, silver, or copper.

Bloch (1954) describes how the Carolingians in France concentrated monetary power by controlling the mint, thus creating a "good money", ending the minting of gold, so rather than paying a sou (shilling) of gold, one paid twelve deniers (pennies) of silver, following Charlemagne's definition 1 live (pound) $=20$ sous (shillings) $=12$ deniers (pennies); the sou and the livre being monies of account representing a real matter, a numerical expression of a certain value in deniers, a system lasting until the $18^{\text {th }}$ century. Einaudi (1936) considers the European monetary system between the $9^{\text {th }}$ and the $18^{\text {th }}$ centuries with a distinction between a monetary unit of contract and a unit of payment as rather common and durable, and he finds that the relation between imaginary money and effective money of payment varied inversively with the amount of the latter.

He shows that with a bimetallic standard, the imaginary money kept the monetary system in equilibrium, where the functional relationship reflected the relative market price between gold and silver, and that with imaginary money, three units had to be correlated: the imaginary monetary unit, the real monetary unit, and the unit of an economic good, so if the prices of both the real monetary unit and the unit of the economic good - the commodity - in terms of the imaginary monetary unit doubled, then the price of the unit of economic good in terms of the real monetary unit remains the same. In such a system, real money, having a market price in terms of imaginary money, provides liquidity. Coin shortages were a problem in medieval France that coincided with debasements and the gold écu replaced the livre as unit of account during the 1577-1602 period (Sargent \& Velde, 2002). The return of the livre suggests that the system with partial monetary separation, using an abstract unit of account, was resilient.

The stability of a bimetallic standard of gold and silver coins could be maintained by adjusting the legal ratio of gold to silver according to the market ratio, Einaudi (1936) argues. Referring to the case of Milan in $1762,{ }^{3}$ he finds that fifty-one gold and silver coins

\footnotetext{
${ }^{3}$ Einaudi's data is from Cesare Beccaria," Del disordine e de' rimedi delle monete nello stato de Milano nell' anno 1762," in Le opere, Vol. I, Florence: Le Monnier, 1854.
} 
were used, most of them foreign, each having its legal ratio expressed in the Milanese money of account, the lire di imperiali, an imaginary money holding the system together. However, he clarifies that it could happen that errors were made, attributing to coins with different metal content - weight and fineness - the same value in imaginary money, the money of account, but were easily adjusted when the coins were of the same metal, either gold or silver. It was more complex for coins, which were coined in two or more different metals.

Einaudi presents a simplifying example, with the initial ratio of gold to silver at 1:12, having only two coins:

i. gold fiorino (florin): weighing 120 grains of fine gold; valued at 24 imaginary lire; and

ii. silver scudo: weighing 120 grains of fine silver; valued at 2 imaginary lire, a twelfth of the gold coin according to the initial ratio.

Einaudi shows how the value of the silver coin varies. Letting the ratio of gold to silver change to $1: 11^{1 / 2}$ and 1:121/2, respectively, he finds how the value changes from 2 imaginary lire to 2.0869 and 1.92, respectively. From this he concludes that the function of the imaginary money in a bimetallic monetary system is to maintain the system in equilibrium by changing the current rate of real money in money of account.

As media of exchange, the two real monies in the example above constitute two liquid assets, while their respective value is expressed in imaginary money. Based on the relative legal rate of the two metals - the current ratio of gold to silver - that should adopt the relative market rate, the value of the liquid assets of enterprises, that is the liquidity of enterprises, in money of account, imaginary money, is maintained by compensating a relative rise or decline by adjusting the price of the real monies used in exchange, thus demanding a higher amount of real money, whose price in imaginary money has fallen.

However, in order to maintain liquidity, enterprises had to adjust their portfolios of liquid assets, shifting from real monies falling relative to the imaginary money into real monies stable relative to the imaginary money. Consequently, they would be able to improve their liquidity by shifting from real monies falling relative to the imaginary money into real monies rising relative to the imaginary money.

However, Bloch (1954) shows that the legal ratio between the two metals used in real money gold and silver - was fixed by the money of account, as general barometer of value, in France during the ancien régime: in 1660, a gold louis with gold content 6.81 gram, equal to 10 livres, and a silver écu with silver content 27.95 gram, equal to 3 livres. According to Bloch, this gives a ratio of approximately 1:13.6, although 1:13.7 would be more accurate $(932 / 68 \approx 13.7)$.

More important, Bloch argues that it may not be totally accurate to talk about a bimetallic standard, since gold was used essentially in international commerce, while most of domestic payments and all small payments were made in silver; and that the kings who paid in silver had an interest in valuing silver coins highly, while the discordance between the legal and commercial rate caused trouble, and the money of account provided the means to establish good order; the monetary system of germinal year XI established a variable ratio between gold and silver. The explanation, Bloch finds in the preceding monetary mutations that according to him followed a pattern of radical debasement, gradual reinforcements, and radical debasement again. They represent monetary mutations, but those are more involved. 
Monetary mutation, Fantacci (2005) calls any variation in the relationships between imaginary money, real money, and metal and he distinguishes two types:

i. Change in metal content at the mint: debasement (decrease), reinforcement (increase)

ii. Change in the tariff: enhancement (increase), abatement (decrease)

He shows that debasement and enhancement have identical effects on metal parity, debasement reducing metal content without affecting the legal value; enhancement by augmenting the legal value without affecting the metal content. For Savoy from 1500 to 1600, he finds exclusive use of debasement for small coins, but almost exclusive use of enhancement for large coins, representing the two exchange circuits: local trade, where extrinsic value matters, and long-distance trade, where intrinsic value matters.

For France in the early 1690s, Bloch (1954) shows how the legal value was changed in a way that looks as enhancements, increases in the tariff. Nevertheless, he calls them debasements, which he finds to be combined with gradual reinforcements. According to Bloch, in 1690 the old silver écu worth 3 livres was replaced by the new silver écu worth 3 livres 6 sous, thus debasing the silver écu by raising the silver écu from 3 livres to 3 livres 6 sous, followed in 1693 with a similar operation raising the silver écu to 3 livres 12 sous; while old coins were invalidated and redeemed at 3 livres 2 sous in 1690 and 3 livres 4 sous in 1693, thus giving the king a profit of 4 and 8 sous, respectively.

Why would the king engage in such activity? As Rolnick et al. (1996) show, seigniorage revenues were substantial in debasement years, but minting volumes increased both during debasement and reinforcement. In France during the ancien régime, the kings aimed at activating the minting of money, and the price of the gold mark increased from 60 livres to 63 livres 10 sous from December 1360 to January 1374, while the price of the silver mark increased from 5 livres to 5 livres 17 sous from April 1360 to October 1373, and debasement with increased tariff were very frequent, thus activating the minting, while enhancement of the coins preserved or increased the seigniorage, according to Landry ([1910] 1969).

Monetary mutation should, therefore, be considered as a means to increase the liquidity of political enterprises. A political enterprise that found sufficient liquidity was the defence by mercenaries. Bloch (1954) refers to transition from feudal military service to mercenaries as a new need created and that debasement gave increased means of payment available to the king. The Hundred Years War between France and England meant an increase in the demand for money. Military innovations in the fourteenth century induced the hire of foreign crossbowmen, but the French fleet also required the hire of foreign ships, according to Miskimin (1963).

In addition, foreign credit was also important. Miskimin (1963) argues that foreign credit mattered to the domestic economy only when included in the coinage, because a reminted foreign loan increased money supply, but still medieval credit relied more upon increasing velocity than the money supply. He mentions how forced loans brought hoardings into circulation, thus increasing velocity, but also that debt instruments, including bills of exchange, did not become means of payment. Nevertheless, as Wicksell ([1906] 1966) argues, bills of exchange increase virtual velocity, thus overcoming the scarcity of money through credit, while Gurley and Shaw (1960) point out that non-monetary indirect securities may increase the supply of loanable funds, thus contributing to liquidity. 
According to Miskimin (1963), the survival of France in the fourteenth century required elaborate fiscal expedients, such as credit, and France and England, both utilized substantial credit operations to finance the war, including loans from foreigners, while both French and English kings tried to prevent the circulation of foreign coins, which had to be carried to the mint. The French ordinance of June 30,1306, stated that foreign gold and silver coins had no exchange rate in the Kingdom of France, but had to be carried to the mint (Saulcy, 1879), thus activating the minting of money and thereby creating seigniorage. This leads us back to the issue of monetary mutations, in particular their relationship with seigniorage.

Rolnick et al. (1996) define monetary mutation as any change in the mint equivalent, which is the ratio of a coin's legal tender value (the official rate in units of account) to its silver or gold content; mint price as the units of account paid per unit of weight for metal; and gross seigniorage as the difference between mint equivalent and mint price. Gross seigniorage increases with the mint equivalent, which in turn increases by raising the legal tender value (enhancement) or decreasing the gold or silver content (debasement).

Rolnick et al. compare the monetary history of England and France during the $14^{\text {th }}$ and $15^{\text {th }}$ centuries and find that in France between 1285 and 1490, there were 123 debasements of the silver currency, out of which 112 with more than 5 percent, but 64 debasements in gold currency, out of which 48 with more than 5 percent, while England enjoyed monetary stability that ended with the Great Debasement from 1542 to 1551.

The gross seigniorage rate - the ratio of gross seigniorage to mint equivalents - they find to be 7.5 percent for silver and 2.0 percent for gold in normal years, increasing to 21.7 for silver and 4.3 for gold during debasement years in France during the 1354-1490 period, but 4.6 percent for silver and 1.1 percent for gold in normal years, increasing to 16.2 percent for silver and 6.9 percent for gold during debasement years in England during the 1280-1600 period. Hence, debasements were important sources of liquidity of political enterprises. In addition, they find that minting volumes increased after both debasements and reinforcements. This implies that the media of exchange expanded. Consequently, monetary mutation increased the liquid assets of political enterprises and liquidity as media of exchange.

In late medieval France, the king determined the metallic value of the unit of account by specifying the number of livres to be struck from the mark of Paris, a metallic unit of weight, while the pied de monnaie, which expresses a relationship between the alloy, face value, and weight of the coin, was used to control the silver coinage, according to Miskimin (1963). He considers the pied de monnaie to be an index of debasement, since the number of livres to be struck from the mark is one fourth of the pied de monnaie. However, this may reflect enhancement.

According to Landry ([1910] 1969), monetary separation allowed the kings to augment and diminish the legal value of money, controlling minting through the pied de monnaie, while there was interaction between the legal value and the market value. In particular, he shows how the tariff chosen by the king influenced the proportion of silver that is minted relative to that used for other purposes. Through this kind of interaction between state and market, the kings were able to influence the minting of money and thus money supply. 
Landry stresses that in France during the ancien régime, the kings were always concerned about activating the minting of money, while the existence of a money of account facilitated monetary mutations. Landry's definition of debasement, which includes enforcement, and of reinforcement, which includes abatement, implies that his concern is metal parity, but still he mentions that enhancement was more frequent, because it was seen as seen as more honorable.

While Landry argues that debasement activated the minting of money to the benefit of the seigniorage, Miskimin states that debasement decreased the amount of metal that had to be brought to mint, but it also increased commodity prices, at least the price of wheat that he considers, although monetary mutation cannot always explain price changes. The price of the commodity increased with debasement, while holding the face value of debased money constant, according to Miskimin. In France, the ordinance of September 8, 1306 stated that weak money will be valued according to its intrinsic value, so that three deniers of it would correspond to one denier of good and strong money (Saulcy, 1879).

Miskimin (1963) stresses that the number of livres struck to the mark matters to money supply, unlike debasement. This means that the unit of account can be adjusted to control liquidity, while media of exchange are subject to market forces, like commodities. The geographic origin of the media of exchange is less important. Miskimin finds that wheat prices were rather insensitive to mint output and metal inflow, because there was alteration in coinage between France, Flanders, and England, reflecting foreign trade.

However, in order to give market enterprises sufficient liquidity, credit became necessary, including bills of exchange, along the lines of Wicksell ([1906] 1966), Meulen (1934), and Bloch (1954), the latter pointing out how the bill of exchange was established in the $13^{\text {th }}$ century to facilitate settlement between different locations in different monies. Hence, bills of exchange belonged to the long-distance exchange circuit and they were therefore very susceptible to debasements, thus explaining why enhancements were made for large coins used in the long-distance exchange circuit. However, the rise of bills of exchange as media of exchange is a matter for further research.

\section{Conclusion}

Liquidity is a crucial link between the financial system and the real economy. Sustainable growth requires that the financial system, through a trial-and-error process, finds the correct liquidity which meets the financing needs of innovation desired by consumers.

In the BFH system that separates a physically defined unit of account from privately issued media of exchange, the amount of the media of exchange is demand-driven, because there is no base money impeding them. Nevertheless, a commodity bundle is problematic in terms of stability of the medium of account, but so is banknote money. In a credit economy, an abstract medium of account with credit media of exchange may be appropriate, as media of exchange can expand beyond bank money.

Monetary separation in pre-modern Europe meant that imaginary money was used as unit of account and real money as medium of exchange. The former was an institution, while the latter to some extent can be seen as a commodity. In the BFH system, the unit of 
account is defined as a commodity bundle, in which each commodity is included in a specific quantity.

Under the gold standard, when the medium of account and medium of exchange functions were united, money was a pure commodity, a specific quantity of gold. In the pre-modern European monetary system, however, the medium of account was independent of any commodity, while coins as media of exchange had an intrinsic value, in that sense, being a commodity, but also an extrinsic value, in that sense, being an institution. Pre-modern money could be seen above all as a clearing device that later with the gold standard turned into a commodity.

Pre-modern money was subject to monetary mutations changing the metal parity of the unit of account, thus economizing on metal, as illustrated by medieval French monetary mutations. Debasements reduced metal content without affecting the legal value, thus decreasing the intrinsic value without changing the extrinsic value, while enhancements augmented the legal value without affecting the metal content, thus increasing the extrinsic value without changing the intrinsic value. This relative increase of extrinsic value to intrinsic value injected liquidity into the real economy, because seigniorage augmented liquid assets of political enterprises and the media of exchange expanded due to greater minting volumes, although enhancement, unlike debasement, seems to have influenced money supply.

The liquid assets of political enterprises improved, but the liquid assets of market enterprises should also have improved, but a credit medium, such as the bill of exchange was necessary. The unit of account can be adjusted to control liquidity, while media of exchange are subject to market forces, like commodities. Unlike the BFH system, where the unit of account is commodity-based, the units of account in pre-modern Europe were based on social convention and could therefore be adjusted to control liquidity.

\section{Acknowledgement}

An earlier version of this chapter with the title "Media of Exchange and Liquid Assets of Political and Market Enterprises: Some Lessons from Pre-Modern Monetary Practices" was presented at the European Association for Evolutionary Political Economy Conference 2010: The Economic Crisis and the Renewal of the European Model(s), Bordeaux, France, October 28-30, 2010.

\section{References}

Bloch, M. (1954). Esquisse d'une historie monétaire de l'Europe, Cahiers des Annales No. 9, Librairie Armand Colin, Paris

Cesarano, F. (1995). The New Monetary Economics and the Theory of Money. Journal of Economic Behavior \& Organization, Vol. 26, pp. 445-455, Reprinted in Cesarano (2008) Cesarano, F. (1998). Providing for the Optimum Quantity of Money. Journal of Economic Studies, Vol. 25, pp. 441-449, Reprinted in Cesarano (2008)

Cesarano, F. (1999). Monetary Systems and Monetary Theory. Kredit und Kapital, Heft 2/1999, pp. 192-208, Reprinted in Cesarano (2008) 
Cesarano, F. (2008). Money and Monetary Systems: Selected Essays of Filippo Cesarano, Edward Elgar, ISBN 978-1-84720-519-3, Cheltenham \& Northampton, MA

Cowen, T., \& Kroszner, R. (1987). The Development of the New Monetary Economics. Journal of Political Economy, Vol. 95, pp. 567-590, ISSN 0022-3808

Cowen, T., \& Kroszner, R. (1989). Scottish Banking before 1845: A Model for Laissez-Faire? Journal of Money, Credit, and Banking, Vol. 21, pp. 221-231, ISSN 1538-4616

Cowen, T., \& Kroszner, R. (1994). Explorations in the New Monetary Economics, Basil Blackwell, ISBN 1-55786-071-8, Oxford and Cambridge, MA

Dembinski, P. H., \& Perritaz, C. (2000). Towards the Break-Up of Money, In: Georg Simmel's Philosophy of Money: A Centenary Appraisal, Backhaus, J. G., \& Stadermann, H.-J. (Eds.), pp.175-200, Metropolis-Verlag, ISBN 3-89518-297-4, Marburg

Einaudi, L. (1936). Teoria della moneta immaginaria nel tempo de Carlomagno alla revoluzione francese. Revista di storia economica, Vol. 1, pp. 1-35

Einzig, P. (1966). Primitive Money in Its Ethnological, Historical, and Economic Aspects (Second Edition, Revised and Enlarged), Pergamon, Oxford

Fantacci, L. (2005). Complementary Currencies: A Prospect on Money from a Retrospect on Premodern Practices. Financial History Review, Vol. 12, pp. 53-61, ISSN 1474-0052

Garrison, R. W. (2001). Time and Money: The Macroeconomics of Capital Structure, Routledge, ISBN 0-415-07982-9, London and New York

Greenfield, R. L., \& Yeager L. B. (1983). A Laissez-Faire Approach to Monetary Stability." Journal of Money, Credit, and Banking, Vol. 15, pp. 302-315, Reprinted in Yeager, L. B. (1997). The Fluttering Veil: Essays in Monetary Disequilibrium, Selgin, G. (Ed.), Liberty Fund, ISBN 0-865-97146-3, Indianapolis, IN

Gurley, J. G., \& Shaw, E. S. (1955). Financial Aspects of Economic Development. American Economic Review, Vol. 45, pp. 515-538, ISSN 0002-8282

Gurley, J. G., \& Shaw, E. S. (with a Mathematical Appendix by Einthoven, A. C.) (1960). Money in a Theory of Finance, The Brookings Institution, Washington, DC

Hayek, F. A. von (1929). Geldtheorie und Konjunkturtheorie, Beitrage zur Konjunkturforschung, Österriechischen Institut für Konjunkturforschung, no.1

Hayek, F. A. von (1931). Prices and Production (with a foreword of L. Robbins), Routledge, London

Hicks, J. R., ([1967] 1979). Critical Essays in Monetary Theory, Clarendon Press, ISBN 0-19828423-3, Oxford

Hicks, J. R., (1977). Economic Perspectives: Further Essays on Money and Growth, Clarendon Press, ISBN 0-19-828407-1, Oxford

Horwitz, S. (2007). Learning, Monetary Exchange, and the Structure of the Economic Universe: An Austrian-Searlean Synthesis. In: Economics and the Mind, White, M., \& Montero, B. (Eds.), pp. 75-88, Routledge, ISBN 978-0-415-77056-9, London and New York

Huerta de Soto, J. (2006). Money, Bank Credit, and Economic Cycles, Ludwig von Mises Institute, ISBN 978-0-945466-39-0, Auburn, AL

Landry, A. ([1910] 1969). Essai économique sur les mutations des monnaies dans l'ancienne France de Philippe le Bel à Charles VII, Bibliothèque de l'École des Hautes Études 185e fascicule, Librairie Honoré Champion, Paris 
Leijonhufvud, A. (1984). Hicks on Time and Money. In: Economic Theory and Hicksian Themes, Collard, D. A., Helm, D. R., Scott, M. F. G., \& Sen, A. K. (Eds.), Oxford University Press, Oxford, Reprinted in Leijonhufvud, A. (2000), Macroeconomic Instability and Coordination: Selected Essays of Axel Leijonhufoud, Edward Elgar, ISBN 1-85278-967-0, Cheltenham

Marmefelt, T. (2009). Human Knowledge, Rules, and the Spontaneous Evolution of Society in the Social Thought of Darwin, Hayek, and Boulding. Journal of Economic Behavior E Organization, Vol. 71, pp. 62-74, ISSN 0167-2681

Menger, C. (1892a). Geld. Handwörterbuch der Staatswissenschaften III vgl. No. 24 (Third Edition (1909) Handwörterbuch der Staatswissenschaften IV), Gustav Fischer, pp. 555610, Jena

Menger, C. (1892b). On the Origin of Money. Economic Journal, Vol. 2, pp. 238-255, ISSN 0013-0133

Meulen, H. (1934). Free Banking: An Outline of a Policy of Individualism, (Second Edition), Macmillan, London

Mises, L. von ([1912] 1924), Theorie des Geldes und der Umlaufsmittel, ( Second Edition, Reprint 2005), Duncker \& Humblot, ISBN 3-428-11882-0, Berlin

Mises, L. von (1928). Geldwertstabilisierung und Konjunkturpolitik, Gustav Fischer, Jena

Miskimin, H. A. (1963). Money, Prices, and Foreign Exchange in Fourteenth Century France, Yale University Press, New Haven and London

Rolnick, A. J., Velde, F. R., \& Weber, W. E. (1996). The Debasement Puzzle: An Essay on Medieval Monetary History. Journal of Economic History, Vol. 56, pp. 789-808, ISSN 1471-6372

Sargent, T: J., \& Velde F. R. (2002), The Big Problem of Small Change, Princeton University Press, ISBN 0-691-11635-0, Princeton and London

Saulcy, F. de (1879). Recueil de documents relatifs à l'histoire des monnaies frappées par les rois de France. Depuis Phillipe II jusqu'à François Ier, Volume 1, Imprimerie nationale, Paris

Schumpeter, J. A. (1911). Theorie der wirtschaftlichen Entwicklung, Duncker \& Humblot, Leipzig

Searle, J. (1999). Mind, Language, and Society: Philosophy in the Real World, Weidenfeld \& Nicholson, ISBN 0-75380-921-4, London

Steuart, J. (1810). Principles of Banks and Banking of Money, as Coin and Paper, Davis, London

Wagner, R. E. (2007). Fiscal Sociology and the Theory of Public Finance, Edward Elgar, ISBN 978-1-84720-246-8, Cheltenham \& Northampton, MA

Wallace, N. (1983). A Legal Restrictions Theory of the Demand for 'Money' and the Role of Monetary Policy. Federal Reserve Bank of Minneapolis Quarterly Review, Vol. 7, pp. 1-7

Wicksell, K. ([1906] 1966). Föreläsningar i nationalekonomi, Häfte II: Om penningar och kredit, (Fifth Edition), Gleerups (first edition: Berlingska), Lund

Woolsey, W. W. (1992). A Model of the BFH Payments System. Southern Economic Journal, Vol. 59, pp. 260-272

Woolsey, W. W., \& Yeager, L. B. (1994), “Is There a Paradox of Indirect Convertibility?" Southern Economic Journal, Vol. 61, pp. 85-95

Yeager, L. B. (1968). Essential Properties of the Medium of Exchange. Kyklos, Vol. 21, pp. 4569, Reprinted in Yeager, L. B. (1997). The Fluttering Veil: Essays in Monetary Disequilibrium, Selgin, G. (Ed.), Liberty Fund, ISBN 0-865-97146-3, Indianapolis, IN 
Yeager, L. B. (1998). Are Markets Like Language? Quarterly Journal of Austrian Economics, Vol. 1, pp. 15-27

Yeager, L. B. (2000). Against Mistaken Moralizing. Quarterly Journal of Austrian Economics, Vol. 3, pp. 49-54

Yeager, L. B. (2001). The Perils of Base Money. Review of Austrian Economics, Vol.14, pp. 251266, ISSN 0889-3047

Yeager, L. B, \& Greenfield, R. L (1989). Can Monetary Disequilibrium Be Eliminated? Cato Journal, Vol. 9, pp. 405-419, Reprinted in Yeager, L. B. (1997). The Fluttering Veil: Essays in Monetary Disequilibrium, Selgin, G. (Ed.), Liberty Fund, ISBN 0-865-971463, Indianapolis, IN 
(C) 2012 The Author(s). Licensee IntechOpen. This is an open access article distributed under the terms of the Creative Commons Attribution 3.0 License, which permits unrestricted use, distribution, and reproduction in any medium, provided the original work is properly cited. 